\title{
COMMENTARY
}

\section{PENN LAW SCHOOL MASS TORTS SYMPOSIUM: A RESPONSE TO PROFESSOR COOPER}

\author{
EDWARD R. BECKER ${ }^{\dagger}$ AND JEROME M. MARCUS ${ }^{\dagger}$
}

Our hats are off to Professor Cooper for his production of a brilliant paper on the legal concerns presented by complex mass torts litigation.' His paper discusses the entire array of complex legal problems and issues raised by the adjudication of mass tort claims. The scope of this Response does not permit us to delve into the specifics of each of the topics that he has addressed; we shall therefore focus on what we believe are the larger issues.

To begin, Professor Cooper's proposed Mass Tort Statute, Mass Tort Civil Rule, and Settlement Class Rule each offer the current best conception of a total solution to the real problems encountered in mass tort litigation. Unfortunately, the quarrels about the various provisions of both proposals demonstrate that all of the constituencies represented here today simply cannot and, as a practical matter, will not, reach a full agreement about a solution. Much of the conflict inherent in these proposals rests in the evaluation of value-determined choices that perforce form the foundations for each attempt to create a workable, guiding statute or rule. Just a partial list of the competing values underlying this debate necessarily includes the differing attitudes on matters such as aggregation versus individualization of claims; the importance of process; tolerance for uncertainty; tolerance for the subjugation of individual claims which present a unique element of plaintiff fault, causation, and damage issues to the "great aggregate"; beliefs in the efficacy of opt-in versus opt-out provisions; perspectives on the fictional nature of legal representation in the mass

† Chief Judge, United States Court of Appeals for the Third Circuit. B.A., University of Pennsylvania, 1954; LL.B., Yale Law School, 1957.

\# Shareholder, Berger \& Montague, P.C. B.A. 1980, M.B.A. 1981, J.D. 1986, University of Chicago.

${ }^{1}$ See Edward H. Cooper, Aggregation and Settlement of Mass Torts, 148 U. PA. L. REV. 1943 (2000). 
torts context; and notions of the appropriate role of federalism.

For analytical purposes, let us grant, however, that the realpolitik at work means that Professor Cooper has made the right assumptions, especially with regard to the aggregation problem. Within this framework, we make the following points, focusing especially on process.

Professor Cooper's proposal illuminates three main points. The first, made abundantly clear by his careful exposition, is the rich and, we believe, overwhelming complexity of the problem. Although Professor Cooper describes a thoughtful-really, an exemplary-solution, we think it clear that a global solution is utterly beyond reach. The diversity of interests, along with the large number of constituencies that espouse them (plaintiff, defendant, and beyond), and the need for value-determined choices as discussed above, make such an endeavor a fruitless and frustrating pursuit.

The second point that Professor Cooper's analysis forces us to confront is that a meaningful solution must inevitably be the product of legislative action. We think this is clear because his thorough explication of the problems at work here shows that these are matters far beyond the limited competence of the courts alone, even under the most expansive possible interpretation of the Rules Enabling Act and similar state law provisions or doctrines. That fact does not mean that other mechanisms, such as rulemaking and didactic exercises like this conference, must be discarded. Such approaches can provide a meaningful aid to the development and operation of a well-tailored act or statute. But real change can be achieved only with a properly fashioned legislative enactment.

The last point we gather from Professor Cooper's presentation is that the usefulness of any study, symposium, or other discussion concerning a solution to the problems generated by mass tort litigation requires the participation of all relevant people and constituencies. Casting an eye over the participants to this symposium, we disagree with the suggestion of Judge Scirica that all of the necessary parties to the dialogue are represented here today. This symposium has rounded up the usual suspects-judges, law professors, and plaintiffs' and defendants' lawyers, who handle both individual and class actions. There are, however, a number of other interested parties and constituencies who are not here and ought to be involved in the development of the solutions: the business executives who decide whether to settle or go forward with litigation and therefore decide whether to "bet the company"; insurance executives; consumers; state attorneys 
general; scientists; economists; and members of Congress.

It is, of course, true that the problem of identifying which people in these categories are the right ones could itself be the topic of a long debate. In the end, some reasonable but arbitrary decisions will have to be made. This list of viable participants once again emphasizes the daunting challenge of creating a solution via consensus, but we think it important to involve all of these constituencies even though we cannot expect them to agree with one another. Even without agreement, the interaction of these different points of view will help the legislatures and the courts to move toward valuable solutions. Perhaps other programs similar to this symposium, such as the upcoming conference in Florida sponsored by Duke Law School, will take up the challenge. We thus suggest expanding the list of presenters and participants at these conferences.

As these academic explorations continue, we believe that it will also be useful to identify the incentives each group faces in evaluating specific solutions. Those incentives, as well as the potential solutions themselves, should be catalogued. We think the result might be a valuable tool for assessing possible approaches to a solution. But a better approach than pure symposia would be the appointment by the Chief Justice of the Supreme Court of a committee that can be charged with the responsibility of drafting formal legislative proposals. This effort could be patterned on such bodies as the White Commission on Circuit Structure. Even better, Congress might create a committee like the Federal Courts Study Committee. The latter had Congressmen on it and-relatedly-actually developed legislation that was adopted.

Leaving aside the manner in which a workable solution may be derived and the form it should take, we would like to offer our own, albeit partial, solution. This solution draws from the premise that the best hope for a practical mechanism to resolve mass tort suits is found in enhancing the ability of the federal courts to manage multistate class actions. In this respect we agree with Ken Feinberg that neither Amchem $^{2}$ nor Ortiz sounds the death knell for multistate class litigation in federal court.

Most mass tort actions in federal court are based on diversity jurisdiction. A huge obstacle to effective management, and sometimes to class treatment itself, is the variation in state laws. To effect an en-

\footnotetext{
${ }^{2}$ Amchem Prods., Inc. v. Windsor, 521 U.S. 591 (1997).

${ }^{3}$ Ortiz v. Fibreboard Corp., 527 U.S. 815, 119 S. Ct. 2295 (1999).
} 
hancement of court managerial authority, we think Congress should enact a choice-of-law statute that would facilitate multistate class action litigation. Such an act would certainly pass constitutional muster. We think that it will be productive to bring pressure on Congress to focus on this type of tool. The way to get something done in Congress is to focus on one measure at a time instead of a whole laundry list, which is what we have done too often.

It is also realistic to try to bring the following mechanisms into existence:

(1) More uniform state laws. As noted above, the existing variations among state laws are problematic. The differences are, as often as not, idiosyncratic and not reflective of policy choices. Especially problematic in national mass tort litigation are the extremes typically found in one or two jurisdictions. The need for different substantive law choices to be made in different states can be respected by having states choose one of several different approaches.

(2) A substantive "best-practices" program. Such a program is in place at the state level on procedural matters, under the aegis of the Conference of State Chief Justices and the National Center for State Courts. It now focuses largely on procedure. It should be expanded to substantive matters, so as to eliminate "outlier" states and counties.

(3) Reform of the law on punitive damages. This should be dealt with either by the best-practices program or, optimally, by a Supreme Court decision that imposes some order in this area.

Finally, in this age of national and even international markets, some areas of substantive law should become subject only to federal regulation and therefore to preemption. The asbestos cases fall in this category, as do many other products liability cases and environmental contamination suits. We believe that the repetitive imposition of punitive damages in mass tort claims, which we find constitutionally problematic, is also best dealt with by a single, generally applicable, federal rule. Such a rule should be imposed by statute if not by constitutional mandate through a Supreme Court decision.

An essential element to any solution, whether it is a choice-of-law statute or a mass tort civil rule, is an increase in the level of cooperation between the federal and state judiciaries. We do not favor Francis 
McGovern's Multidistrict Litigation ("MDL") proposals" whereby a federal judge assigns state cases. The state courts would resent this procedure, and it would generate animosity between the two judicial systems. Rather, we should enhance those mechanisms currently in place and co-opt the "outliers" that produce distorted results. We can also increase the number and breadth of joint federal-state databases, such as the Third Circuit Death Penalty Data Base, that provide information useful to courts in both the state and federal systems.

We note in this regard that while courts cannot solve all of the problems presented by mass tort litigation, there are several things they can do without legislation to avoid or minimize some of the problems. Cooperation among federal courts before which similar matters are pending can already be enforced through the Judicial Panel on Multidistrict Litigation, which is empowered to avoid duplication of various efforts such as discovery by consolidating all similar cases before a single court. When cases are pending in both state and federal fora, no panel is currently empowered to move all cases to a single jurisdiction, but there is no reason why judges in different jurisdictions cannot cooperate with one another and agree to proceed, or even to rule, in lockstep.

There is also no reason, for instance, why cooperation between state and federal cases cannot produce a single plan of discovery, proposed to and adopted by both the state and federal courts hearing the cases. Such cooperation can be facilitated by the distribution of documents to all such fora and by the simple expedient of the judges in each court speaking with one another over the telephone. A number of cases have benefited from cooperation of this kind.

We would also encourage the adoption of a settlement-class rule, something that we think can be done consistent with the charter of Amchem. Although the Supreme Court's decision in Amchem does not bind the Federal Rules Committee, the Court's decision represents sound policy in that it insures cohesiveness and fidelity to due process with respect to the adequacy of legal representation, including any related conflicts of interest. This means that any revision to Rule 23 to allow for settlement classes should continue to require the presence of

${ }^{4}$ See Francis E. McGovern, Toward a Cooperative Strategy for Federal and State Judges in Mass Tort Litigation, 148 U. PA. L. REv. 1867, 1892 (2000) (proposing that the transferee judge be allowed to "oversee pretrial discovery for both federal and state cases" in order to eliminate redundant discovery; that the MDL judge be allowed to try individual cases from a broad geographical distribution; and that the MDL judge also be permitted to "remand a limited number of cases to state and federal courts for trial"). 
the factors enumerated by Rule $23(\mathrm{a}),{ }^{5}$ and satisfaction of the predominance test $t^{6}$ even in a settlement context.

On the subject of settlement, courts can also take useful steps to alleviate the risk that separate sets of plaintiffs' lawyers are played off against one another to the detriment of the respective classes they each represent. We speak here of reports of efforts by defendants in various mass tort cases to cause the plaintiffs' camps to bid against one another to settle the cases. The existence of separate cases being handled by competing groups of lawyers means that a defendant can in effect induce the groups to bid against one another. Because the cases are handled by plaintiffs' lawyers on a contingency basis, a group that fails to reach a settlement will get nothing if another group does come to terms with the defendant. This creates the risk of suboptimal settlements that are not in the best interest of the class. This problem can be prevented, or at least ameliorated, if the courts before which the competing cases are pending cooperate on hearing and approving settlements. If that cannot be achieved, it is possible for a court-at least one that has exclusive jurisdiction over a claim pending before it-to order the defendant to provide that court with notice of any settlement it plans to enter into that would release such claims. Such an order does not bar the defendant from entering into the state court settlement; it merely requires that the federal court be given notice and the opportunity to assess the settlement before it is entered into. This may enable the state and federal judges to consult with one another about the merits of the settlements, to the ultimate benefit of the class.

As Professor Cooper's paper shows by revealing the complexities of this issue, the key question facing those of us interested in developing a meaningful solution to the problem of mass tort litigation is how to get Congress interested. We believe the formation of a committee

\footnotetext{
${ }^{5}$ Federal Rule of Civil Procedure 23(a) requires:

One or more members of a class may sue or be sued as representative parties on behalf of all only if (1) the class is so numerous that joinder of all members is impracticable, (2) there are questions of law or fact common to the class, (3) the claims or defenses of the representative parties are typical of the claims or defenses of the class, and (4) the representative parties will fairly and adequately protect the interests of the class.
}

FED. R. CrV. P. 23(a).

${ }^{6}$ The predominance test is outlined in Federal Rule of Civil Procedure 23(b)(3), which allows a class action to be maintained if "the court finds that the questions of law or fact common to the members of the class predominate over any questions affecting only individual members, and that a class action is superior to other available methods for the fair and efficient adjudication of the controversy." FED. R. GrV. P. 23(b) (3). 
such as we have described can lead us toward a workable consensus that has a real chance of being enacted by Congress. A solution to the challenges of complex mass torts litigation can be fashioned. It will take time and hard work, but we can make real progress. As we try to craft such a solution, however, we think it absolutely essential that all participants have clear in their minds the difference between substance and procedure. Many, if not most, of the participants in the debates on these issues will have a substantive perspective: they will either favor expanded recovery rights for those affected by mass torts, or they will be hostile to such rights and seek contraction of the right to obtain damages or other relief. To the extent that proposals are advanced and assessed by those with such a substantive perspective, however, we think it essential that substance be clearly identified and divorced from procedure. 
